\title{
STUDY OF DUPLICATED OPTIC CANALS IN EASTERN INDIAN HUMAN SKULLS
}

\author{
GYANARANJAN NAYAK*, BISWA BHUSAN MOHANTY, SAURJYA RANJAN DAS
}

Department of Anatomy, IMS and SUM Hospital, SOA University, Bhubaneswar - 751 003, Odisha, India. Email: drgrn82@gmail.com

\author{
Received: 20 June 2016, Revised and Accepted: 29 August 2016
}

\section{ABSTRACT}

Objective: The duplication of optic canals is a rare anomaly found in both sexes, all ages, and various races. The present study was carried out to find the incidence of duplication of optic canal and to study its clinical and developmental significance.

Methods: The study included 100 dry human skulls of both the sexes and various age groups. These skulls were studied grossly and morphologically to find out duplication of the optic canals.

Results: Additional optic canals were found in 3 skulls (3\% cases). Out of them, 2 cases (2\%) presented bilateral duplication, whereas in only one case $(1 \%)$, it was unilateral.

Conclusion: Knowledge of additional optic canals is of paramount importance in performing surgical exploration of the optic canal during removal of tumors or decompression of optic canals or surgically accessing the cavernous sinus or sella turcica.

Keywords: Optic canal, Duplication, Anatomy, Skull.

(C) 2016 The Authors. Published by Innovare Academic Sciences Pvt Ltd. This is an open access article under the CC BY license (http://creativecommons org/licenses/by/4. 0/) DOI: http://dx.doi.org/10.22159/ajpcr.2016.v9s3.13586

\section{INTRODUCTION}

The optic canal (usually 1 pair in humans) leads from the apex of the orbit to the middle cranial fossa. The canal is bound by the two roots of the lesser wing of the sphenoid and transmits the optic nerve and the ophthalmic artery, the nerve being medial to the artery [1]. Duplication of the optic canal is a very rare anomaly [2-4]. This variation is reported in various subjects irrespective of age, sex, and race [5]. Duplications of the optic canal have earlier been reported by Warwick [2], Choudhry et al. [3], and Singh [6]. In these cases, the optic canal is seen to carry the optic nerve, whereas the duplicated canal carries the ophthalmic artery. This variation is mostly due to ossification of the dura mater between the optic nerve and ophthalmic artery as the smaller, duplicated canal is occupied by the ophthalmic artery. [7] The present study was carried to obtain the incidence of the duplicate optic canal and derive its clinical and developmental significance.

\section{METHODS}

The study was conducted on 100 skulls available in the Department of Anatomy of a Medical College in Odisha. These skulls were between 20 and 70 years of age and belonged to both the sexes. The skulls were thoroughly examined for the duplication of the optic canals. Patency of the main and duplicate canals was tested by passing a probe through the canals. Length of the main canal was measured along the medial wall by a marked needle. It was not feasible to measure the length of the accessory canals. The thickness of the septum separating the main and accessory canals could not be measured either mainly due to unapproachability of the region.

\section{RESULTS}

Out of the 100 skulls examined, 3 skulls (3\%) showed duplication of optic canal. 2 of the skulls (2\%) showed bilateral duplication, whereas a lone skull (1\%) showed duplication only on the right side as depicted in Table 1. Fig. 1 shows the orbital openings of the main and duplicated optic canals, whereas Fig. 2 shows the cerebral ends of the main and duplicated canals.

In each of the 3 skulls showing duplication, the larger main canal was in the usual position directed posteromedially upward and was continuous with the anterolateral end of sulcus chiasmaticus. The smaller or duplicated canal was inferolateral to the main canal in the lesser wing of sphenoid. The main and accessory canals were separated by bony septa. The length of the main canal was between 8 and $10 \mathrm{~mm}$. In our study, the duplicated optic canals were mainly found in skulls above 40 years of age. This finding may be attributed to the fact that with increasing age, there is more chance of ossification of the dura which covers the optic nerve and ophthalmic artery [5].

\section{DISCUSSION}

Duplication of the optic canal has been reported by many authors. Ghai et al. [8] have reported 5 skulls (2.57\%) with duplication of optic canal. Out of the 5 skulls, 3 skulls $(1.5 \%)$ had bilateral, and 2 skulls (1.03\%) had unilateral duplication. Sweta and Kumar [9] have reported duplication in 3 skulls (4.47\%). Out of the 3 skulls, 1 skull (1.49\%) had bilateral, and 2 skulls (2.98\%) had unilateral duplication. Patil et al. [10] have reported an overall incidence of $2.75 \%$ with bilateral duplication in 3 skulls $(0.75 \%)$ and unilateral duplication in 8 skulls (2\%) Singh [6] has reported duplication of optic canal in 13 skulls (2.98\%), of which, 7 skulls (1.6\%) had bilateral and 6 skulls $(1.38 \%)$ had unilateral duplication. Shinde et al. [11] have reported a single case (1\%) with unilateral duplication. In the study of Berlis et al. [12], there was an incidence of $2.5 \%$ of the duplicate optic canal.

In the present study, the average length of the optic canal was found to be $8-10 \mathrm{~mm}$. Patil et al. [10] have found the similar length of $8-10 \mathrm{~mm}$ in their study. Choudhry et al. [3] have estimated the average length of optic canal in their study as $9-11 \mathrm{~mm}$. Ghai et al. [8] have reported the average length as $8-12 \mathrm{~mm}$ in their study. Thus, many authors have reported about the incidence of the duplicate optic canal in their studies. Usually, the larger canal transmits the optic nerve, whereas the smaller canal transmits the ophthalmic artery. Hence, the smaller canal is also called ophthalmic canal [10].

There are three basic stages in the development of the optic canal [13]. In the first stage, a cartilaginous foramen is formed in the $12^{\text {th }}$ week of intrauterine life. This is followed by the second stage, in which the cartilaginous foramen is ossified almost by 16 weeks. Finally, the bony 
Table 1: Incidence of duplicate optic canals

\begin{tabular}{llll}
\hline $\begin{array}{l}\text { Number } \\
\text { of skulls } \\
\text { studied }\end{array}$ & $\begin{array}{l}\text { Number of } \\
\text { skulls showing } \\
\text { duplication (\%) }\end{array}$ & $\begin{array}{l}\text { Number of } \\
\text { skulls with } \\
\text { bilateral } \\
\text { duplication (\%) }\end{array}$ & $\begin{array}{l}\text { Number of } \\
\text { skulls with } \\
\text { unilateral } \\
\text { duplication (\%) }\end{array}$ \\
\hline 100 & $3(3)$ & $2(2)$ & $1(1)$ \\
\hline
\end{tabular}
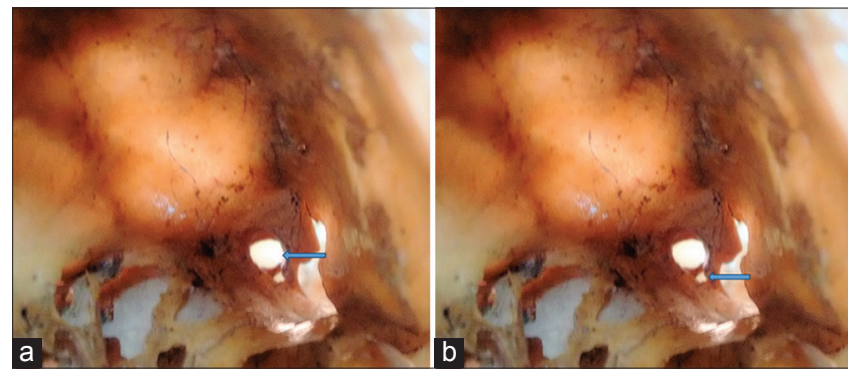

Fig. 1: (a) Orbital opening of the main optic canal. (b) Orbital opening of the duplicated optic canal

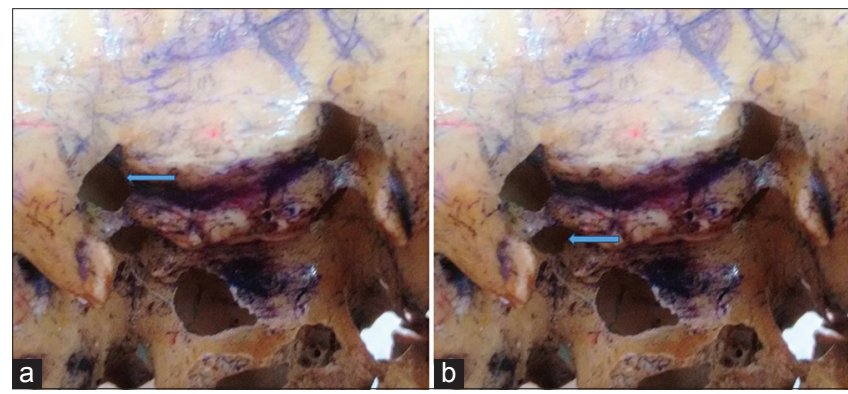

Fig. 2: (a) Cerebral opening of the main optic canal. (b) Cerebral opening of the duplicated optic canal

foramen is converted into a bony canal in the $5^{\text {th }}$ month of intrauterine life. The development of the optic canal is a part of the development of lesser wing of sphenoid. The transformation of the optic foramen into the optic canal is dependent on the normal development of the lower root of the lesser wing of sphenoid which is called the optic strut. The duplication of the optic canal has a developmental basis and is mostly the result of anomalous growth of the optic strut. Leon [14] is of the opinion that the radiological findings of the optic canal, the large orbital opening in children, and the variable course of the proximal portion of the ophthalmic artery can be explained on the basis of the developmental pattern of the optic strut.

\section{Probable causes of duplication of optic canal}

1. Le-Double [5] suggested that the ossification of the dura mater covering the optic nerve results in a divided optic canal

2. Keyes [15] opines that a bony projection in the inferolateral wall of the optic canal when enlarged divides the optic canal, and a smaller accessory canal is formed

3. Wolff [16] put forward that the ossification of the fibrous tissue separating the optic nerve and ophthalmic artery divides the optic canal

4. Augier [3] opined that the duplication is the result of the persistence of a foramen "le trouemetoptique." He supposed that the foramen is formed due to an aberrant ophthalmic vein
5. The duplication may develop from the anomalous growth of the optic strut [14].

\section{Significance of the duplication of optic canal}

It is useful to know the presence of double optic canal while surgically exploring the optic canal during tumor removal and decompression [8] This knowledge is also essential in surgically approaching the cavernous sinus or sella turcica [8]. The optic canal can be explored safely if the course of the ophthalmic artery is known to the surgeon. Hence, the use of pre-operative angiography is of paramount importance in these cases [17]. Optic canal anomalies can be mistaken for clinoid process pneumatization, carotid-clinoid foramen, defect in greater wing of sphenoid or posterior ethmoid air cells [9]. Anomalies in optic canal can pose a threat during endoscopic optic nerve decompression and in injuries of the sphenoethmoidal region [10]. Duplicate optic canals can be confusing during interpreting and evaluating computed tomography scans or X-rays of the sphenoethmoid region [18]

\section{CONCLUSION}

We found double optic canal in 3 skulls in our study. In this anomaly, the anatomical relationship of the optic nerve with the ophthalmic artery is maintained. This anomaly has a developmental basis as highlighted by our study. The knowledge of this variation is highly significant for clinicians particularly radiologists and surgeons operating on head and neck.

\section{REFERENCES}

1. Standring S. Gray's Anatomy. $39^{\text {th }}$ ed. London: Churchill Livingstone; 2005. p. 688-700.

2. Warwick R. A juvenile skull exhibiting duplication of the optic canals and subdivision of the superior orbital fissure. J Anat 1951;85(3):289-91.

3. Choudhry R, Choudhry S, Anand C. Duplication of optic canals in human skulls. J Anat 1988;159:113-6.

4. Choudhry R, Anand M, Choudhry S, Tuli A, Meenakshi A, Kalra A Morphologic and imaging studies of duplicate optic canals in dry adult human skulls. Surg Radiol Anat 1999;21(3):201-5.

5. Le-Double AF. Traite'des Variations des Os Du Crane de I'. Homme Paris: Vigol Fre'res. 1935; 1903. p. 372.

6. Singh M. Duplication of optic canal in adult Japanese human skulls. J Anat Soc India 2005;54(2):1-9.

7. White LE. An anatomic and X-ray study of the optic canal. Beston Med Surg J 1942;189:741-8.

8. Ghai R, Sinha P, Rajguru J, Jain S, Singla M. Duplication of optic canal in human skull. J Anat Soc India 2012;61(1):33-6.

9. Sweta VR, Kumar SS. Accessory optic canal in South Indian dry skull. J Pharm Sci Res 2014;6(5):224-5.

10. Patil GV, Kolagi S, Padmavathi G, Rairam GB. The duplication of the optic canals in human skulls. J Clin Diagn Res 2011;5(3):536-7.

11. Shinde VS, Patil R, Channabasanagouda, Mallikarjun M. Study of duplication of optic canal in hundred dry human skull bones. Int J Biomed Res 2013;04(11):633-5.

12. Berlis A, Putz R, Schumacher M. Direct and CT measurements of canals and foramina of the skull base. Br J Radiol 1992;65(776):653-61.

13. Scheuer L, Black S, Christie A. Developmental Juvenile Osteology in Head, Neck and Dentition. London: Elsevier; 2000. p. 90.

14. Leon KE. Embryology of the normal optic canal and its anomalies. An anatomic and roentgenographic study. Invest Radiol 1966;1(5):346-62.

15. Keyes J E L. Observation on four thousand optic foramina in human skulls of known origin. Arch Ophthalmol. 1935; 13(4): 538-68.

16. Wolff E. Anatomy of the Eye and Orbit. $7^{\text {th }}$ ed., Vol. 15. London: H.K Lewis; 1976.

17. Slavin KV, Dujovny M, Soeira G, Ausman JI. Optic canal: Microanatomic study. Skull Base Surg 1994;4:136-44.

18. Vanitha, Fatima T, Kadlimatti HS. Unilateral duplication of optic canal A case report. IOSR J Dent Med Sci 2014;13(4):82-3. 